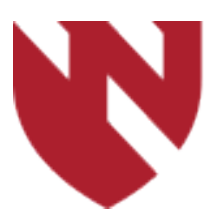

December 2019

\title{
Hepatitis B Vaccination in Advanced Chronic Kidney Disease: A Quality Improvement Project at a Veteran Affairs CKD Clinic
}

\author{
Faizan Syed \\ University of Nebraska Medical Center \\ Gayle Gillispie \\ University of Nebraska Medical Center \\ Valerie Shostrom \\ University of Nebraska Medical Center \\ Denise Murcek \\ University of Nebraska Medical Center \\ Linda Flores \\ University of Nebraska Medical Center
}

See next page for additional authors

Tell us how you used this information in this short survey.

Follow this and additional works at: https://digitalcommons.unmc.edu/gmerj

Part of the Higher Education Commons, and the Medicine and Health Sciences Commons

\section{Recommended Citation}

Syed, F., Gillispie, G., Shostrom, V., Murcek, D., Flores, L., Florescu, M., Fillaus, J., , Tendulkar, K. Hepatitis B Vaccination in Advanced Chronic Kidney Disease: A Quality Improvement Project at a Veteran Affairs CKD Clinic. Graduate Medical Education Research Journal. 2019 Dec 13; 1(1).

https://digitalcommons.unmc.edu/gmerj/vol1/iss1/26

This Conference Proceeding is brought to you for free and open access by DigitalCommons@UNMC. It has been accepted for inclusion in Graduate Medical Education Research Journal by an authorized editor of DigitalCommons@UNMC. For more information, please contact digitalcommons@unmc.edu. 


\section{Hepatitis B Vaccination in Advanced Chronic Kidney Disease: A Quality Improvement Project at a Veteran Affairs CKD Clinic}

\section{Creative Commons License}

\section{c) (1)@ $\Theta$}

This work is licensed under a Creative Commons Attribution-Noncommercial-No Derivative Works 4.0 License.

\section{Authors}

Faizan Syed, Gayle Gillispie, Valerie Shostrom, Denise Murcek, Linda Flores, Marius Florescu, Jennifer Fillaus, and Ketki Tendulkar 
not to pre plasma exchange levels. In spite of the rise between therapies, each treatment resulted in progressive decline in the overall FT4. Cumulatively, after 4 sessions, there was a $54 \%$ reduction in FT4 levels.

Conclusions: When primary synthesis of thyroid hormone is not interrupted because of intolerance to antithyroid medication, FT4 rises following each session of plasma exchange. This trend describes the extraction efficacy of FT4.

https://doi.org/10.32873/unmc.dc.gmerj.1.1.025

\section{Hepatitis B Vaccination in Advanced Chronic Kidney Disease: A Quality Improvement Project at a Veteran Affairs CKD Clinic \\ Faizan Syed, Gayle Gillispie, Valerie Shostrom, Denise Murcek, Linda Flores, Marius Florescu, Jennifer Fillaus, Ketki Tendulkar}

\section{Mentor: Ketki Tendulkar \\ Program: Nephrology}

Hepatitis B vaccination is recommended in all patients with end stage renal disease (ESRD). However, only 50-60\% of these patients achieve protective antibody levels if immunized after starting dialysis. Strategies to overcome this low seroconversion rate include a 6 month vaccination schedule starting earlier (CKD stage 4 and 5), to ensure immunity when patients progress to ESRD.

This was a Quality Improvement program to immunize pre-dialysis patients. Patients who were $\mathrm{HBsAb}$ negative were offered vaccination on a 6 month schedule $(0,1$ and 6 months) with either Recombivax ${ }^{\mathrm{TM}}$ or Engerix $^{\mathrm{TM}}$ and HBsAb titers were checked 2-3 months later. Titers $\geq 12 \mathrm{mIU} / \mathrm{mL}$ were indicative of immunity. Patients who did not seroconvert were offered booster schedule of 3 higher strength $(40 \mathrm{mcg}$ ) doses. Descriptive statistics were used to describe this cohort.

We screened 122 patients with CKD stage 4 and 5 (GFR $<29 \mathrm{ml} / \mathrm{min})$. These included 121 males and one female. The median age of this cohort was 68 years (range 38-92 years). During the 2 study-year period, 13 had improved GFR ( $>30 \mathrm{ml} / \mathrm{min}$ ) and hence were excluded from this analysis. Of the remaining 109 patients, 8 were seropositive at baseline. Nineteen patients progressed to ESRD, 5 were noncompliant, 12 refused vaccination, six patients had died and one was on hospice. Nineteen patients have started the original vaccination series, while 42 have not started yet. Only one patient (5.3\%) achieved seroconversion, while 3 patients have started the booster series.
Logistic issues including lack of physician time in clinic, coordination with other visits, non-compliance with nursing injection appointments over a 6 month period were the main limitations in this project. Given the low seroconversion rate, albeit in a small cohort, studies should be conducted using a higher initial dose in patients with CKD. Another option would be to vaccinate patients with earlier stages of CKD to increase the rate of immunity should they progress to ESRD. We plan to increase awareness among patients and nursing staff about the importance of this vaccine.

https://doi.org/10.32873/unmc.dc.gmerj.1.1.026

\section{Pilot Project to Assess and Improve Neurosurgery Resident and Staff Perception and Feedback to Neurosurgery Residents for Self-Improvement Goal Formation \\ Steven O Tenny, Kyle P Schmidt, William Thorell}

\section{Mentor: William E Thorell}

Program: Neurosurgery

Background: The Accreditation Council for Graduate Medical Education (ACGME) has pushed for more frequent and comprehensive feedback for residents during their training but there is scant evidence for how neurosurgery residents view the current feedback system as used to provide self-improvement information and goal formation.

Objective: We set forth to assess neurosurgery resident and staff perceptions of the current resident feedback system in providing Specific, Meaningful, Achievable, Realistic, and Timely (SMART) goals. We then wished to create a pilot project to improve the most unfavorably viewed aspect of the feedback system.
Methods: We conducted an anonymous survey of neurosurgery residents and staff at an academic medical institution to assess SMART goals for resident feedback and used the results to create a pilot intervention to address the least favorable viewed part. We conducted a post-intervention survey to see if perceptions had improved for the targeted intervention.

Results: Neurosurgery residents and staff completed an anonymous online survey indicating timeliness of feedback was the most significant concern for feedback for neurosurgery residents. A simple anonymous feedback form was created and distributed monthly to neurosurgery residents, staff and nurses with the results reported monthly to each resident for six months. In the postintervention survey neurosurgery residents and staff had changed from a negative to nonnegative opinion on the timeliness of resident feedback $(\mathrm{p}=0.01)$.

Conclusion: The required ACGME feedback methods may not be providing adequate feedback for goal formation for selfimprovement for neurosurgery residents. Simple interventions, such as anonymous feedback questionnaires, can improve neurosurgery resident and staff perception of feedback to residents for self-improvement and goal formation. https://doi.org/10.32873/unmc.dc.gmerj.1.1.027 